\title{
A new species of Muellera (Leguminosae, Papilionoideae, Millettieae) with a revised identification key to the genus in Venezuela
}

\author{
Marcos José da Silva ${ }^{1,3}$ \& Ana Maria Goulart de Azevedo Tozzi ${ }^{2}$
}

\begin{abstract}
Muellera fragiliflora, a new species from the states of Bolívar and Cojedes, in Venezuela, is here described and illustrated. Information on its distribution, conservation status, flowering and fruiting as well as their morphological relationships with its closest relatives, $M$. sanctaemarthae and $M$. tubicalyx, is provided. This new species is distinguished by its flowers, bracts, and bracteoles without glandular pellucid dots, flowers with pedicel 5-6 mm long, bracteoles opposite and situated on the upper third part of the pedicel, as well as in having fragile flowers and turgid fruits. A dichotomous key is provided to the recognition of the Venezuelan species of Muellera.
\end{abstract}

Key words: endemism, Fabaceae, South America, taxonomy.

\begin{abstract}
Resumo
Muellera fragiliflora, uma nova espécie dos estados de Bolívar e Cojedes na Venezuela, é aqui descrita e ilustrada. Informações sobre sua distribuição, status de conservação, floração e frutificação, bem como sobre suas relações morfológicas com suas espécies mais próximas, M. sanctaemarthae e M. tubicalyx, são fornecidas. Esta nova espécie se diferencia por suas flores, brácteas e bractéolas sem pontos pelúcidos glandulares, flores com pedicelo de 5-6 mm compr., bractéolas opostas e situadas no terço superior do pedicelo, bem como por ter flores frágeis e frutos túrgidos. Uma chave dicotômica é fornecida para o reconhecimento das espécies venezuelanas de Muellera.
\end{abstract}

Palavras-chave: endemismo, Fabaceae, América do Sul, taxonomia.

\section{Introduction}

The tribe Millettieae is one of the most diverse and morphologically complex among the tribes of the family Leguminosae subfamily Papilionoideae, presenting 45 genera and approximately 900 species (Schrire 2005). In the Americas, Millettieae is represented by 13 genera, and circa of 250 species growing especially in wet or seasonal dry forests, associated or not with rivers bank.

Among the milletioid American genera, Muellera L.f. has been traditionally recognized by its moniliform or submoliform fruits. This genus has an interesting and problematic taxonomic history, sometimes being treated as a synonym of the genus Lonchocarpus (Geesink 1981, 1984; Fortunato \& Palese 1997; Sousa \& Sousa 1981;
Tozzi 1989, 1992) or as an independent genus (Burkart 1969; Herman 1965; Polhill 1981; Schrire 2005). Muellera was also regarded as monoespecific, consisting of M. moniliformis L.f. (type species), or as biespecific, consisting also by M. fluvialis (Lindm.) Burk. (Burkart 1969; Schrire 2005).

Until recently, the genus Muellera was composed of the two aforementioned species. However, after the phylogenetic studies of Lonchocarpus and its allies (e.g., Dahlstedtia Malme, Deguelia Aubl., Derris Lour., Phylenoptera Fenzl), based on morphological and molecular data, Silva (2010) verified its paraphyletism by adding Dahlstedtia, Bergeronia Micheli, Margaritolobium Harms and Muellera to its circumscription.

\footnotetext{
${ }^{1}$ Universidade Federal de Goiás, Inst. Ciências Biológicas, Depto. Botânica, C.P. 171, 74001-970, Goiânia, GO, Brazil.

${ }^{2}$ Universidade Estadual de Campinas, Depto. Biologia Vegetal, Inst. Biologia, C.P. 6109, 13083-970, Campinas, SP, Brazil.

${ }^{3}$ Author for correspondence: marcos_agrorural@hotmail.com
} 
Silva et al. (2012) also clearly verified that the phylogeny of Lonchocarpus encompasses three morphological clades, one of which was informally designated by the author as "Laxiflori clade". According to Silva et al. (2012), the "Laxiflori clade" has a robust bootstrap support (95-100\%) and includes the species of Lonchocarpus sect. Laxiflori (Benth.) Taub., Bergeronia sericea Micheli, and Margaritolobium luteum (Johnston) Harms. After solving nomenclatural questions and based on morphological peculiarities and geographic distribution of "Laxiflori clade" Silva et al. (2012) transferred the species of the latter to the genus Muellera, thereby enlarging the circumscription of the latter. Silva (2010) also is reviewing the taxonomy of Muellera and recognized 26 species distributed mainly in South America, with exception of M. monilis (L.) M.J. Silva \& A.M.G. Azevedo and M. fendleri (Benth.) M.J. Silva \& A.M.G. Azevedo, since both reach Central America. Silva (2010) mentioned that Muellera differs from Lonchocarpus by its pseudoracemes with flowers geminate, but not Y-shaped, distributed along the rachis, membranaceous floral parts with staminal tube, filaments, and anthers usually indumented, bracteoles situated along the upper half of the pedicel, fruits indehiscent and usually not thickened along the upper margin.

During the examination of some Muellera collections from the Neotropics, as part of the revision of the genus, executed by the first author of this article, several specimens were found that could not be assigned to any known species in this genus. One of these species is herein described and illustrated. This species, as well as some others occurring in Venezuela, are contrasted with a dichotomous key. It is worth to emphasizing that the species contrasted in the dichotomous key have been treated in the genus Lonchocarpus in previous studies of the Venezuelan flora (Pittier 1917, 1944; Poppendieck 1992), but they were transferred recently (Silva et al. 2012) to the genus Muellera.

After the addition of the species described here, the genus Muellera is going to be represented by eight species in Venezuela.

\section{Material and Methods}

The morphological description and illustration of the new species are based on traditional taxonomic methods. The morphological terminology adopted in the description follows Silva (2010). The conservation status of the new species was determined based on the analysis of herborized collections studied applying the IUCN red list criteria (IUCN 2016). The map with the potential geographical distribution of the new species was generated using the software Quantum GIS Development Team (QGIS) version 2.8.1. Finally, the key to identify all Muellera taxa occur in Venezuela resulted from the analysis of approximately 350 collections from herbaria (BM, C, G, GH, F, GUYN, IAN, INPA, K, M, MICH, MO, NY, P, PEUFR, RB, UEC, US, VEN), whose acronyms follow Thiers (continuously updated).

\section{Results and Discussion}

Taxonomic treatment

Muellera fragiliflora M.J. Silva \& A.M.G. Azevedo, sp. nov. Type: VENEZUELA. COJEDES: Distrito Girardot al Sur de El Baul, $8^{\circ} 10^{\prime} \mathrm{N}, 68^{\circ} 18^{\prime} \mathrm{W}, 70 \mathrm{~m}$, IV.1986, f1., M. Ramia \& R. Ortiz 8513 (Holotype: VEN!; Isotype: VEN!).

Fig. 1

Species M. sanctaemarthae affinis, sed fructis velutino-ferrugineis, laciniis calycinis saltem tres auctis, bracteis eglandulatis, floribus subsessilibus vel breviter pedicellatis, pedicellis apicem versus bracteolis oppositis apicis instructis recedit.

Shrubs or small trees 6-7 m tall; bark greyish to brownish; young branches cylindrical to angulate, yellowish-pubescent, the same indumentum on the pulvinus, petiole, petiolule, rachis and midrib on lower surface; mature branches glabrous, lenticelate; stipules caducous. Leaves 7-9-foliolate; pulvinus $2.5-3 \mathrm{~mm}$ long, transversally rugose; petiole $1.2-1.8 \mathrm{~cm}$ long, rachis $4-4.8 \mathrm{~cm}$ long, both subquadrangular, strongly canaliculate above; petiolule $1.9-2 \mathrm{~mm}$ long, leaflets $1.9-2.6 \times 1.1-1.3 \mathrm{~cm}$, opposite, elliptic to ovate-elliptic, subrounded to cuneate base, rarely oblique ( $1^{\text {st }}$ pair), emarginate to retuse or more rarely acute apex, papyraceous to chartaceous, bright green on the upper surface, pubescent along the midrib, pubescent to tomentose on the lower surface, brownish to yellowish or hyaline trichomes; distance between each pair of the leaflets 1-1.4 cm long; brochidodromous venation, secondary veins impressed on both surface, each forming an angle of $35-45^{\circ}$ with the midvein, reticulate tertiary veins. Pseudoracemes axillary, sometimes in the endings of leafless branches, erect, flowers laxly distributed in an alternate-spiral arrangement along the rachis; 
peduncle $0.6-1.3 \mathrm{~cm}$ long, rachis $4.3-5.3 \mathrm{~cm}$ long, both cylindrical to angulate, slender; primary bract (at the base of inflorescence), secondary bracts (situated below the insertion of the pedicels) $0.7-0.8 \times 0.7 \mathrm{~mm}$ long, broadly ovate, tertiary bracts (at base of each pedicel) $1.2-1.3 \times 0.3-0.4$ $\mathrm{mm}$, ovate; bracteoles (situated on apex of pedicel) 1.7-1.8 mm long, lanceolate, acute apex, opposite, bracts and bracteoles, caducous, external ferrugineous-tomentose and without glandular

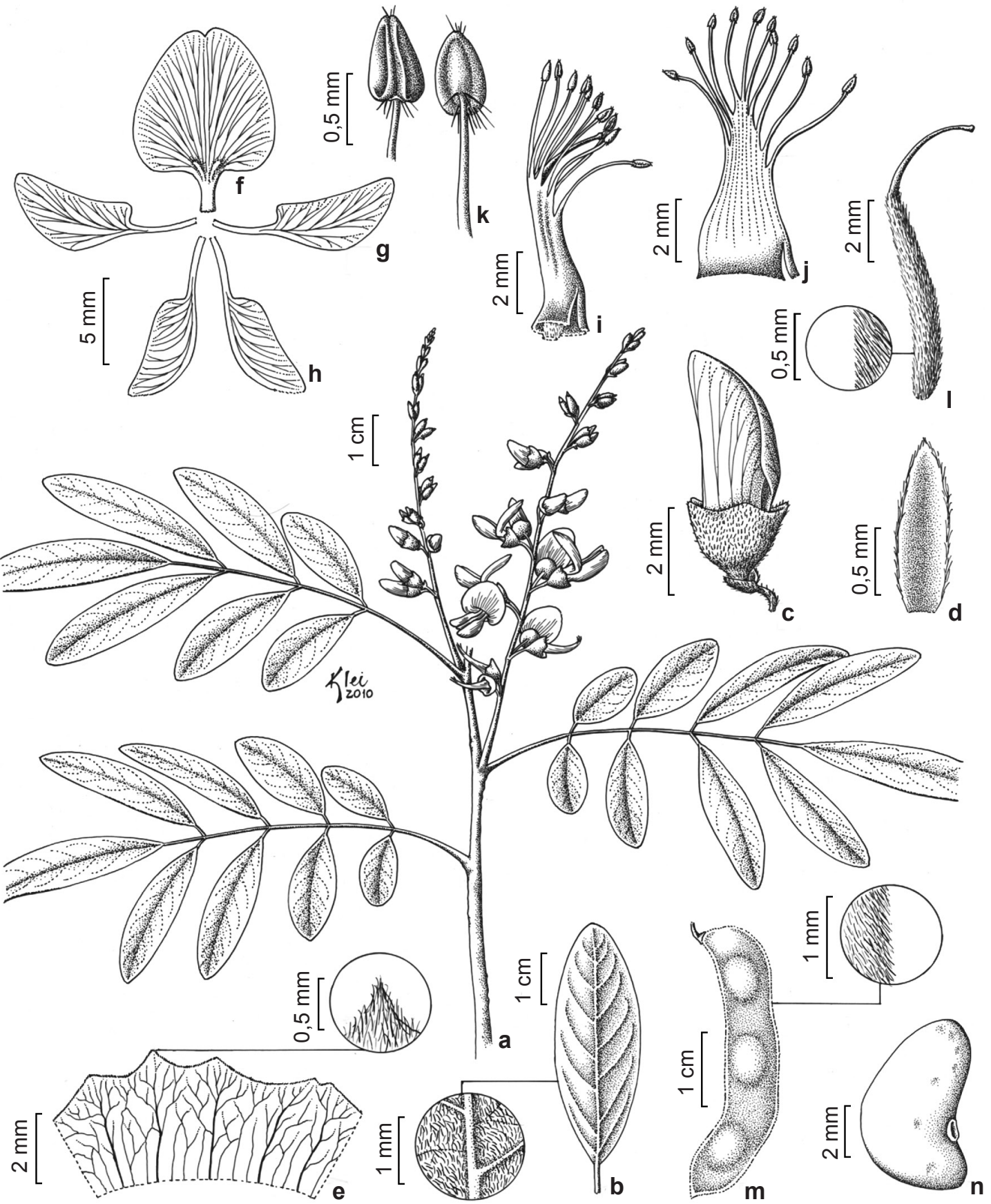

Figure 1 - Muellera fragiliflora - a. flowering branch; b. leaflet; c. floral bud; d. bracteoles; e. calyx opened out; f. standard; g. wings; h. keel petals; i. staminal tube; j. open staminal tube; k. anthers (dorsal and ventral views); 1. gynoecium; m. fruit; o. seed. (a-1. M. Ramia \& R. Ortiz 9513; m,n. Wilmer Diaz; o. Acosta \& J. Perez 6409). 
pellucid dots. Flowers whitish, calyx and corolla without dots; pedicel 5-6 mm long, slender, ferrugineous-tomentose; calyx 2-2.1 × 3.8-3.9 $\mathrm{mm}$, campanulate, short ferrugineous-tomentose externally, cuneate basally; vexillary lobe triangular bifid, the 3 carenal ones, triangular, acuminate; standard 8.9-9 × 8.2-8.3 mm, broadly ovate to orbiculate, apex emarginate, broadly attenuate base and bicallose basally, linear callous, internally glabrous and short sericeous on the central-apical region of the dorsal surface, claw 3.9-4.1 mm long; wings 7.4-7.5 × 3-3.1 mm, falcate, apex obtuse, base subtruncate on the vexillar margin, sericeous on the central-apical region of the dorsal surface, claw 4.2-4.3 mm long.; keels petals 7.9-8 $\times 2.9-3 \mathrm{~mm}$, falcate, umbonate, apex obtuse, base obtuse on the vexillar margin, claw $4.2-4.4 \mathrm{~mm}$ long; staminal tube $5.2-5.3 \times 1.8-1.9 \mathrm{~mm}$, submembranaceous, glabrous, slightly bicallose basally; anthers $0.7-0.8 \mathrm{~mm}$, ovoid, pubescent; ovary $5.9-6 \mathrm{~mm}$ long, linear, curved on carenal margin, densely sericeous, styles $5-5.2 \mathrm{~mm}$ long, conspicuously curved, sericeous, subcapite stigma, stipe $8.9-9 \mathrm{~mm}$; ovules 7 , reniform; hypanthium c. $8 \mathrm{~mm}$ long, asymmetric. Fruit $2.5-4.2 \times 0.7-0.8 \mathrm{~cm}, 1-2$ seeded, indehiscent, oblong to falcate without constrictions between the seeds, cuneate at base, obtuse to acuminate at apex, chartaceous, vexillary margin nerviform, ferrugineous-velutinous, persistent style. Seeds $8.7-8.8 \times 5-5.1 \mathrm{~mm}$, irregularly reniform, broadly elliptical in cross section, dark brown, smooth hilum, broadly elliptic to suborbicular.

Additional specimen examined (Paratypes): VENEZUELA. Estado de Bolívar: Município del Caroní, origin Criollo, between San Felix and Cerro de Hacha or long of the Orinoco River, $8^{\circ} 27^{\prime} \mathrm{N}, 62^{\circ} 31^{\prime} \mathrm{W}$, 10-20 m, 20.VII.2003, fr., W. Diaz, O. Acosta \& J. Perez 6409 (GUYN, VEN).

Distribution and habitat: Muellera fragiliflora is known so far from states of Bolivar, municipality of Caroni, and Cojedes, District of Giradort, to South of El Baul, Venezuela (Fig. 2), growing in seasonal dry forest along of the banks of Orinoco River.

Relationships and characterization: Muellera fragiliflora forms, with $M$. denudata (Benth.) M. Sousa, M. fendleri (Benth.) M.J. Silva \& A.M.G. Azevedo, M. monilis (L.) M.J. Silva \& A.M.G. Azevedo, M. sanctaemarthae (Pittier) M.J. Silva \& A.M.G. Azevedo and M. tubicalyx (Pittier ex Poppend.) M.J. Silva \& A.M.G. Azevedo a set of species very similar morphologically to those that are often misidentified in herbaria material.
These species occur specially in the northern portion of South America (Brazil, Colombia, Guyana, and Venezuela), being Muellera fendleri, $M$. fragiliflora, $M$. sanctaemarthae, and $M$. tubicalyx mainly Venezuelan, while $M$. denudata, M. tozziana M.J. Silva, and M. monilis are spread principally in Brazil, although the latter also reaches Mexico.

Among these species, $M$. fragiliflora is more related to $M$. sanctaemarthae and M. tubicalyx, which share similarities in floral morphology and, in some cases, in leaflets. However, M. fragiliflora differs consistently from its closest relatives due to its flowers, bracts, and bracteoles without glandular pellucid dots, flowers with pedicel $2.3-2.5 \mathrm{~mm}$ long, calyx 3.8-3.9 mm wide, not subtruncate, bracteoles opposite on the upper third part of the pedicel, as well as turgide fruits, oblong to falcate, subglobose in cross section, thickened on the upper margin, and densely ferrugineous-velutinous. Muellera sanctaemarthae has calyx 5.5-6 mm wide, subtruncated and with glandular pellucid dots, pedicels 7-8 $\mathrm{mm}$ long, and lanceolate to oblongorbicular or orbicular fruits, glabrous to glabrescent, yellowish, and with nerviform upper margin. Muellera tubicalyx has subsessile flowers (pedicel circa $1.5 \mathrm{~mm}$ long), persistent bracts and bracteoles with glandular pellucid dots, opposite bracteoles situated at the base of the calyx, calyx 2-3 mm wide, cuneate, and oblong to oblong-falcated fruits.

Conservation Status: Muellera fragiliflora is known in only two places in Venezuela. Due to the absence of detailed information on the distribution of this species and accurate data about

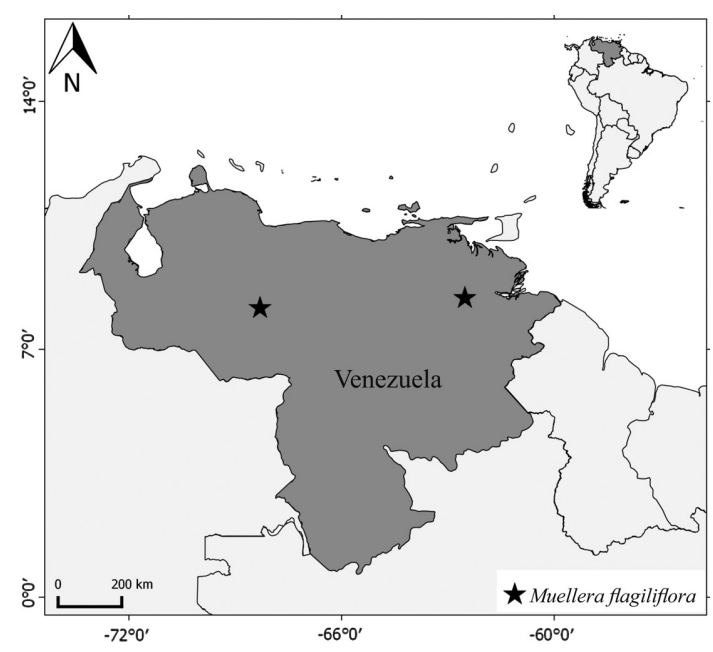

Figure 2 - Distribution map of Muellera fragiliflora. 
its populations, we suggest to include it in the category Data Deficient (DD) according to IUCN Red List criteria (IUCN 2016).

Common names: known as "majomo menudito" in Venezuela.

Etymology: the specific "fragiliflora" refers to the fragile flowers of the new species.
Due to the species of Muellera present in the Venezuela are frequent and occur usually in seasonal dry forests, near or not, to river banks, and considering that them still are found in American and European herbaria under the name Lonchocarpus, we present here an identification key to identify it.

\section{Key to species of Muellera from Venezuela}

1. Fruits moniliform; leaves usually 5 -foliolate, rare 3 or 7 -foliolate Muellera monilis

1'. Fruits samaroid; leaves usually 7-9-foliolate

2. Petals yellow; fruits papyraceous and spotted

Muellera lutescens (Pittier) M.J. Silva \& A.M.G. Azevedo

2'. Petals purple; fruits chartaceous to woody and not spotted....

3. Leaf rachis, petiole and lower surface of the leaflets densely yellowish-velutinous or silvery, rare strigulose; upper surface of the leaflets often bulate; fruits ferruginous to brownishvelutinous with seminal region surrounded by a dark brown blotch ........... Muellera fendleri

3'. Leaf rachis, petiole and lower surface of the leaflets glabrous to rarely glabrescent; upper surface of the leaflets usually plane; fruits glabrous to glabrescent with seminal region not surrounded by a blotch

4. Pedicel 7-8 mm long, fruits glabrous to glabrescent, yellowish and plane to linear in cross section Muellera sanctaemarthae

4'. Pedicel less than $4 \mathrm{~mm}$ long; fruits strigulose to velutinous, brownish to ferrugineous, lanceolate to subglobose in cross section.

5. Flowers with pedicel up to $1.5 \mathrm{~mm}$ long; calyx $2-3 \mathrm{~mm}$ wide; bracts and bracteoles persistent. Muellera tubicalyx

5'. Flowers with pedicel 2.3-4 mm long; calyx 3.8-5 mm wide, bracts and bracteoles caducous

6. Leaves always 5-foliolate; androecium diadelphous Muellera lutea (Johnston) M.J. Silva \& A.M.G. Azevedo

6'. Leaves 7-9-foliolate; androecium pseudomonadelphous .....

7. Bracts, bracteoles and calyx with dots; bracteoles alternate or subopposite situated on the upper third of pedicel, persistent; inflorescence robust, glabrescent to densely tomentose with conspicuous glandular pellucid dots along the rachis Muellera denudata

7'. Bracts, bracteoles and calyx without dots; bracteoles opposite, situated on apex of pedicel, caducous; inflorescence delicate, glabrescent, without glandular pellucid dots Muellera fragiliflora

\section{Acknowledgments}

We thank the National Council for Scientific and Technological Development - Conselho Nacional de Desenvolvimento Científico e Tecnológico (CNPq, processo $\mathrm{n}^{\circ}$ 140609/20067) for supporting the first author; the São Paulo Research Foundation - Fundação de Amparo à Pesquisa do Estado de São Paulo (FAPESP process number 2008/57095-5); the Kew Latin American
Research Fellowship (KLARF Programme) that funded a three month visit to European herbaria, especially B, BM, G, K, M, OXF, and P; the Programa de Pós-graduação em Biologia Vegetal and to the Departmento de Biologia Vegetal da Universidade Estadual de Campinas. We also thank the curators of the herbaria for facilitation of the view of their collections and the artist Klei Rodrigo de Sousa for the line drawing of the new species. 


\section{References}

Burkart A (1969) Leguminosas nuevas o críticas VII. Darwiniana 15: 501-549.

Fortunato RH \& Palese R (1997) Una nueva combinación en el género Lonchocarpus Kunth (LeguminosaeMillettieae): Lonchocarpus fluvialis (Lindm.) Fortunato \& Palese. Candollea 52: 509-511.

Geesink R (1981) Tephrosieae (Benth.) Hutch. In: Polhill RM \& Raven PH. Advances in legume systematics. Vol. 2. Royal Botanic Gardens, Kew. Pp. 245-260.

Geesink R (1984) Scala Milletiearum. A survey of the genera of the tribe Millettieae (LeguminosaePapilionoideae). Leiden Botanical Series. Vol. 8. EJ Brill and Leiden University Press, Leiden. Pp. 1-131.

Hermann FJ (1965) Lonchocarpus. In: Woodson RE \& Schery RW et al. (eds.) Flora of Panama. Annals of the Missouri Botanical Garden 52: 39-47.

IUCN (2016) Guidelines for using the IUCN red list categories and criteria. Version 12 . Prepared by the standards and petitions subcommittee. Gland and Cambridge: IUCN. Available at $<$ http://jr.iucnredlist. org/documents/RedListGuidelines.pdf $>$. Access on 10 December 2016.

Pittier H (1917) The Middle American species of Lonchocarpus. Contributions from the United States National Herbarium 20: 37-93.

Pittier H (1944) Leguminosas de Venezuela I. Papilionáceas. Ministerio de Agricultura y Cría 5: 96-105.

Poppendieck HH (1992) New taxa of Lonchocarpus (Fabaceae: Millettieae) from the Venezuelan Guayana. Novon 2: 53-57.
Polhill RM (1981) Papilionoideae. In: Polhill RM \& Raven PH (eds.) Advances in legume systematics, part 1. Richmond, Surrey. Royal Botanic Gardens, Kew. Pp. 191-208.

Schrire BD (2005) Tribe Millettieae. In: Lewis GP, Scrhire B, Mackinder B \& Lock M (eds.) Legumes of the world. Royal Botanic Gardens, Kew. Pp. 367-387.

Silva MJ (2010) Filogenia de Lonchocarpus s. lat. e revisão dos gêneros Dahlstedtia Malme e Muellera L.f. Tese de Doutorado. Universidade Estadual de Campinas, Campinas. 497p.

Silva MJ, Queiroz LP, Tozzi AMGA, Lewis GP \& Sousa AP (2012) Phylogeny and biogeography of Lonchocarpus sensu lato and its allies in the tribe Millettieae (Leguminosae, Papilionoideae). Taxon 61: 93-108.

Sousa MS \& Sousa MP(1981) New world Lonchocarpinae. In: Polhill RM \& Raven PH (eds.) Advances in legume systematics, part 1. Richmond, Surrey: Royal Botanical Gardens, Kew. Pp. 261-281.

Thiers B [continuously updated] Index Herbariorum: a global directory of public herbaria and associated staff. New York Botanical Garden's Virtual Herbarium. Available at $<$ http://sweetgum.nybg. org/ih/>. Access on 10 December 2016.

Tozzi AMGA (1989) Estudos taxonômicos dos gêneros Lonchocarpus Kunth e Deguelia Aubl. no Brasil. Tese de Doutorado. Instituto de Biologia, Universidade Estadual de Campinas, Campinas. 341p.

Tozzi AMGA (1992) Lonchocarpus monilis (L.) Az.Tozzi, comb. nov. (Leguminosae - Papilionoideae): considerações nomenclaturais e taxonômicas. Revista Brasileira de Botânica 15: 151-155. 